Epiphany 2003

\section{Dalmatian Winter}

'Nous descendons l'Adriatique par un temps épouvantable; impossible de voir autre chose que les côtes brumeuses de l'Illyrie ...', Gérard de Nerval wrote, in early January 1843, going south, by boat. I headed north, recently, and saw the same, or didn't.

Travelling to the Mediterranean for more than 50 years by bicycle, train, boat, car or plane, I knew that around the turn of the year metereologic conditions are not favorable. So I didn't want to go. But, in the fiftieth year of union with my dear wife, and in the 21 st century for that matter, I didn't get my will. So we went. Mild and sunny at the beginning, on Epiphany the tide turned and we were left without electricity, i.e. without heating, toilet, water, cooking, computer and television, in our 'Shangri La', the island hideout of Iž (Eso of old) off the coast and the old Dalmatian capital of Zadar (Zara of yesteryear). Epiphany is a special day for me, I have outlined that in previous 'diaries' and for sure this has a relation to my stay in Jerusalem and the Sisters of Zion in the valley below Hadassah Ein Karem (and Bethlehem right across the hill).

I busied myself with a rather complex review for the leading journal and carried a load of books with me. I could finish it, but, once stalled on site, could not deliver it in the time requested. Therefore, the day after Epiphany, we made a desperate attempt to catch the early morning boat, but, alas, the Egyptian darkness in a place without a single light, public or private, just made me walk right into the inundated harbor. The 'bora' blowing and knee-deep in the waves, retreat was the only solution. Donning shawl, parka, gloves, sitting in our place and looking at the (battery-driven) watch filled the hours. Neighbors, our friendly colleagues in Zagreb and our sons at home kept us abreast of metereology and the masses of snow accumulating all over Central and Southeastern Europe. Mobile telephones had to be operated with restraint because reloading was not possible without current. The bill nevertheless will be sizeable. Eventually electricity was restored, but roads were blocked, along the coast and on the inland route. The ferry out of Zadar into Rijeka appeared to be the only solution. Expensive, time-consuming, but comfortable, it worked, and with a 3-day delay we were on the mainland again and I was in for a pleasant surprise.

Again after a small controversy with my wife, I pushed it through to leave the car in Rijeka and take the direct train to Vienna, a 9-hour trip. For the latter we had to wait 5 hours in the above city and - unexpectedly - I found out that the most extensive and permanent exhibition on Glagolitica was open right across the hotel lobby where we wanted to spend the in-between hours, in the University Library of Rijeka. A golden opportunity to beef up my (small) knowledge of these texts, monuments, replicas and history. Thanks to my collaboratrice from Zagreb I was a bit knowledgeable already and thanks to her husband I had been taken to some of the original places all over the Istrian Peninsula.

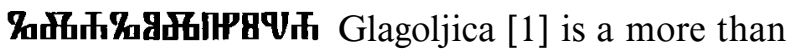
1,000-year-old alphabet, originally designed before the Kyrillic alphabet used by some of the Eastern Slavs nowadays. Dating back to Kyrill and Methodius, to Old Moravia and her Christianization, the surviving texts are mainly kept in what is Croatia of today [2]. Importantly it may be mentioned that the Glagolitic alphabet still follows the old Semitic (Hebrew) order of aliph-bet-gimel-dalet kept in Greek since antiquity and obvious also in Russia's Kyrillic script of today. For the Croatians it is a national treasure and a historic heritage and shown with pride where displayed, e.g. in Beram in Central Istria or on the Baška and Valun Stones, the Plomin inscription as oldest trace, in breviaries and missals or in the Istarski Razvod, settling the borders between the Serenissima, the Aquileian Patriarch and the Counts of Pazin (Mitterburg, Pisino) in 1275 (the latter's territory fell to the Hapsburgs exactly one century later).

\section{KARGER}

Fax+ 41613061234

E-Mail karger@karger.ch www.karger.com 
The lady custodian of this exhibition was kind enough to guide me through and explain details to me so that my poor knowledge substantially increased. As a personal detail I dare mention that last summer, the above-mentioned colleague and husband of my collaboratrice in the inter-academy of sciences project of iconography in dermatology presented me with a Tshirt bearing a Glagolitic inscription. The moment when I entered the secretariat of the Rijeka University Library to present myself and my request to see the exhibition, I unbuttoned my shirt a little and showed the two lady custodians that the stranger from over the mountains knew what he was asking for. A surprised smile was the answer.

What was it then? Mere incidence, a 'capriole' of the weather, serendipity or all together? I opt for serendipity and metereology. So be it. A happy morning anyway and thereafter a boring train ride to $\mathrm{Vi}$ enna.
Back home I had not seen that much snow in the streets since the late 1940s and when I cleared my car next day, I had to shovel away more snow than I ever had done before in the 42 years I drive a car.

Events may be expected, unexpected, both. Sometimes there is a combination as it happened here. Learning, learning is the eternal privilege academia offers, as exemplified here even under adverse circumstances.

\section{References}

1 Fučić B: Glagoljski Natpisi. Zagreb, Croatian Academy of Sciences and Arts, Hrvatska akademia znanosti i umjetnosti, 1982.

2 Fatović-Ferenčić S, Duerrigl M-A: Graffiti - Visual memory of Croatian history. Croatian Med J 1999;40:554-555. 